\title{
Potential for land use change to dairy in Southland, New Zealand: Impact on profitability and emissions to air and water
}

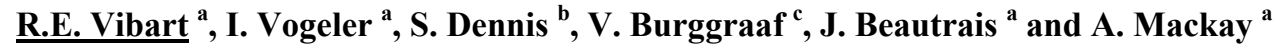 \\ ${ }^{a}$ AgResearch - Grasslands Research Centre, Private Bag 11008, Palmerston North 4442, New Zealand. \\ ${ }^{b}$ AgResearch - Lincoln Research Centre, Lincoln, New Zealand. ${ }^{c}$ AgResearch-Ruakura Research Centre, \\ Hamilton, New Zealand. \\ Email: ronaldo.vibart@agresearch.co.nz
}

\begin{abstract}
Southland has witnessed a pronounced change in its agricultural landscape in recent years. Greater profitability of dairy relative to sheep farming has led to a large number of dairy conversions over the last 20 years, with the scope for further substantive conversions into the future. The economic and social benefits have been extensively reported, but less is understood about the environmental impacts associated with this land use change. To investigate the potential effect of land use change from sheep and beef to dairy on economic and environmental outcomes in the Southland region of New Zealand, farm-scale enterprise simulation models were linked with spatially explicit land resource information. By overlaying individual farm parcels with land resource information, land area and topography data for each farm were attained.
\end{abstract}

Estimated pasture production (PP) for each land use capability (LUC) Class provided indicative data for the modelling exercise on the productive use of the land across the region. The approach provided a method for the expansion of farm scale modelling to a regional scale. A representative DairyNZ Production System 3 was used to investigate the influence of increasing dairy cow numbers and associated inputs at the farm level. A representative sheep and beef farm was also modelled. To account for a dairy support area, used to carry dry cows during the winter, a second step involved the modelling of a larger System 3 dairy farm that included a milking platform area and an adjacent support area. This farm system was considered for regional up-scaling to allow for a more comprehensive capture of nutrient losses and financial outcomes.

Estimates of annual nitrogen (N) leaching values from dairy farms ranged from 21 to $44 \mathrm{~kg} \mathrm{~N} / \mathrm{ha}$, and were higher for farms with greater pasture production potential, due to the greater amount of $\mathrm{N}$ cycling and increased number of urine patches from the higher number of livestock numbers carried. Annual $\mathrm{N}$ leaching from the sheep and beef farms ranged from 8 to $17 \mathrm{~kg} \mathrm{~N} / \mathrm{ha}$. Annual greenhouse gas (GHG) emissions were also higher from farms with greater productive potential, ranging from 7.1 to $15.4 \mathrm{t} \mathrm{CO}_{2}$-e/ha for dairy and from 2.1 to $6.9 \mathrm{t} \mathrm{CO}_{2}$-e/ha for sheep and beef farms. In contrast to leaching, GHG emissions were higher from poorly-drained soils compared with well-drained soils; annual nitrous oxide $\left(\mathrm{N}_{2} \mathrm{O}\right)$ emissions accounted for $22 \%$ and $35 \%$ of total GHG emissions from dairy farms on well- and poorly-drained soils, respectively, and up to $40 \%$ from sheep and beef farms on poorly-drained soils.

The new dairy farms resulting from conversion would largely fall in an N leaching range of 25 to $31 \mathrm{~kg} \mathrm{~N} / \mathrm{ha}$ and have GHG emissions of 7.0 to $10.5 \mathrm{t} \mathrm{CO}_{2}$-e/ha. Depending on future regional regulations that may be implemented, a large number of potential dairy farms might leach more $\mathrm{N}$ than the allowable limit, and mitigation techniques will need to be implemented. A shift in land use from the current $15 \%$ of land area under dairying to a potential $46 \%$ led to a large increase in regional profit (76\%). The environmental impact from this land use change, however, became substantial, with regional nitrate leaching increasing by $34 \%$ and GHG emissions by $24 \%$. Conversion of more farms into dairying increased farm profit, $\mathrm{N}$ leaching and GHG emissions in the region compared with the current situation. It must be noted, however, that the up-scaling of potential dairy conversion was based on land resources defined by the productive potential of the landscapes found in Southland and that the actual level of conversion could differ substantially if additional or different farming scenarios were tested.

Keywords: Southland, Dairy, Sheep, Beef, Farmax, Overseer 


\section{INTRODUCTION}

The national milking herd in New Zealand is fast approaching 5.0 million, an increase of over 700,000 cows since the 2006/07 season (New Zealand Dairy Statistics, 2012). Conversely, total sheep and beef numbers have decreased 7.2 and 0.6 million, respectively, during the same period (Statistics New Zealand, 2013). Southland, New Zealand's southern-most region with a long tradition of sheep farming, has witnessed a pronounced change in its agricultural landscape in recent years. Dairy cow numbers increased from about 200,000 to over 500,000 between $2000 / 01$ and $2011 / 12$. This equates to an increase from less than $6 \%$ to almost $11 \%$ of the national herd, with associated increases in milksolids (MS) production per cow and per hectare (New Zealand Dairy Statistics, 2012).

Much of the regional land use change in Southland has occurred at the expense of sheep and beef farming, on gentle slopes with reliable summer rainfall that favour the more intensive farming conversion to dairying (Figure 1). The greater profitability of dairy relative to sheep farming has led to a large number of dairy conversions over the last 20 years (Beukes et al., 2011), with the potential for sustained conversion rates into the future (Monaghan et al., 2007). The conversion from an often low-input sheep and beef farm to a dairy farm is typically associated with greater amounts of feed (concentrates, supplements and off-farm grazing) and $\mathrm{N}$ fertiliser inputs to sustain large increases in per hectare production. The economic and social benefits have been extensively reported, but less is understood about the environmental impacts associated with this land use change (Monaghan et al., 2007).

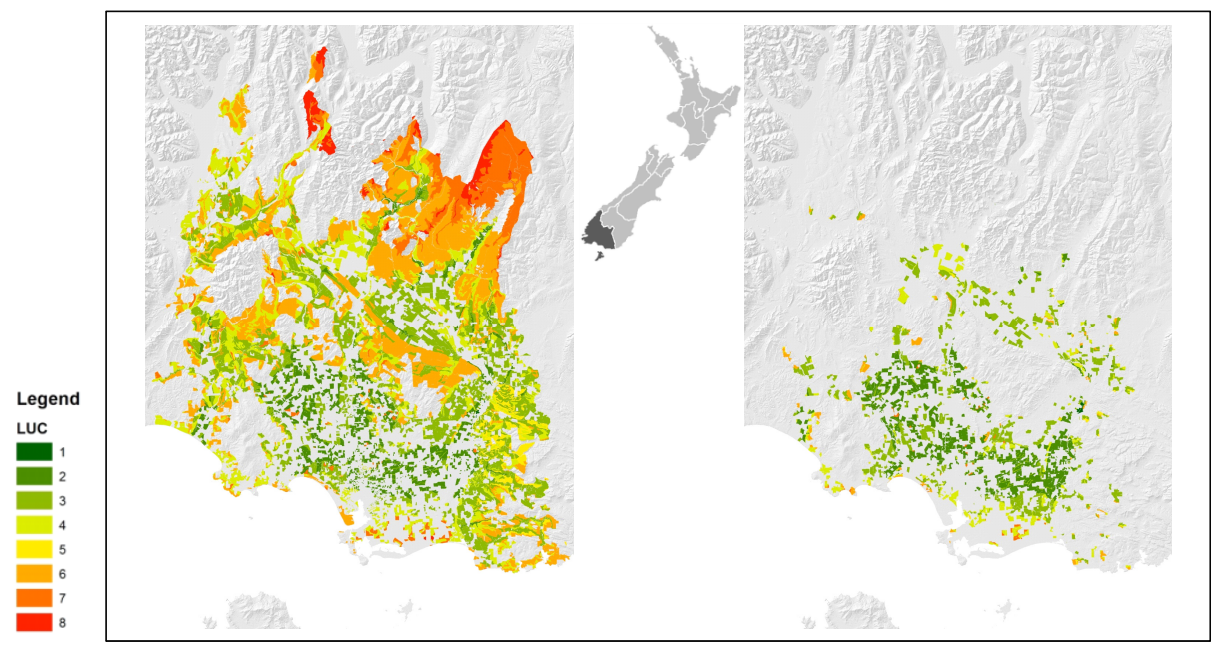

Figure 1. Land use capability (LUC) classes of land currently used for sheep and beef (left) and dairy farming (right) in Southland, New Zealand.

Concerns about the environmental effects of nutrient enrichment of water bodies from intensive livestock operations are rising. The National Policy for Freshwater Management directs regional councils to set water quality limits for freshwater objectives (NPS, 2011). Policy development to achieve these objectives will require extending controls which currently apply to point source discharges, a very small percentage of total discharges, to diffuse losses from agricultural land (Monaghan et al., 2007).

To assess the long-term implications of land use and farming practice changes on ground and surface water quality at scales beyond the farm, information on the current and future likely spatial arrangement of land use activities would be advantageous in regional policy and planning processes. Aggregating on-farm production data and nutrient outputs from nutrient budgeting models across landscapes to explore the implications of land use beyond individual farm boundaries requires the linking of whole-farm models to land resource information. In this paper we investigate the merits of an approach that links spatially discrete land resource information (NZLRI, AgriBase ${ }^{\circledR}$ ) with farm-scale simulation $\left(\right.$ Farmax $^{\circledR}$ ) and associated nutrient budget models $\left(\right.$ OVERSEER $\left.^{\circledR}\right)$ to assess potential land use change from sheep and beef to dairy and to quantify the impact of land use change on the regional economy and the environment.

\section{METHODS}

\subsection{Location, Land Resource Data and Modelling Assumptions}


Southland covers an area of almost 1.7 million hectares (ha), of which $65 \%$ was under pastoral farming in 2007 (Statistics New Zealand). According to AgriBase $^{\circledR}$ (AsureQuality, 2012), a spatial and demographic census of all known New Zealand farms, approximately $15 \%$ of the pastoral farmed land is in dairying and $84 \%$ is in either mixed sheep and beef or sheep farming. By overlaying the individual farm parcels from AgriBase $^{\circledR}$ with information from the Land Resource Information (LRI) system (Landcare Research, New Zealand), land area, LUC classes, topography, soil type and drainage class were obtained for each farm. Using the LUC system (Lynn et al., 2009), land was grouped into eight classes reflecting potential sustainable use, with Class 1 to 7 being potentially suitable for pastoral grazing (Class 1 with the highest productive potential and Class 7 with the most limitations to pastoral use) (Figure 1). Farming LUC classes (and percentages of land area) in Southland include Class $1(0.1 \%)$, Class $2(13.4 \%)$, Class $3(29.8 \%)$, Class $4(20.3 \%)$, Class 5 (2.2\%), Class 6 (25.1\%), and Class 7 (9.1\%).

Before setting up the farm models, the potential productive capacity of a ryegrass/white clover mixed pasture fixing N biologically under a "typical sheep and beef farming system" was estimated for each LUC land unit. For New Zealand, the potential productive capacity is listed under "attainable potential carrying capacity" in the extended legend of the LUC worksheets. These estimates of sheep carrying capacities (ewes/ha) for each land unit from the 1980's provided a basis for calculating the potential annual pasture production (PP; $\mathrm{kg}$ $\mathrm{DM} / \mathrm{ha}$ ) across the region, irrespective of current land use. Seven PP classes were derived from the data through the following steps:

1. An average sheep carrying capacity value was calculated from the area-weighted averages of the individual LUC land units within each LUC class;

2. It was assumed that ewes only consumed $70 \%$ of the pasture grown to convert sheep numbers to pasture production;

3. Pastures on dairy farms produced an additional $7 \%$ to account for improved pasture genetics and differing grazing management (Smith, 2012).

The spatially discrete estimates of potential pasture production for each PP Class (Figure 2) were used to inform the farm systems modelling.

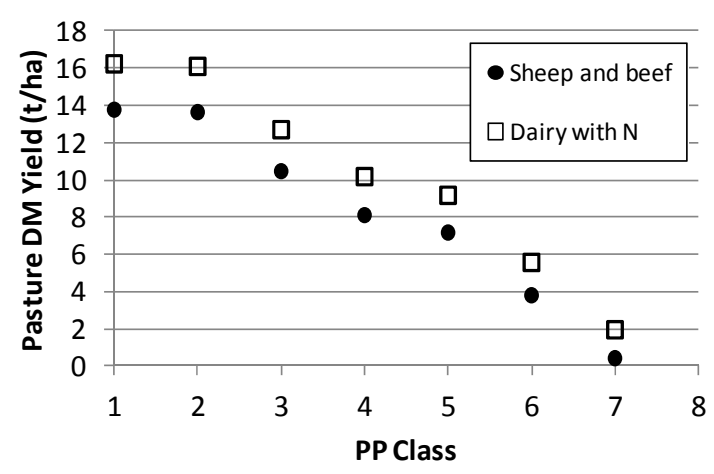

Figure 2. Estimates of annual pasture production for sheep and beef $(\bullet)$ and dairy $(\square)$ farms in Southland.
Two drainage classes were defined based on the New Zealand Soil Classification (NZSC) drainage classes (Landcare Research); poorly drained soils NZSC drainage classes 1-3 (very poor, poor and imperfectly drained) and well drained soils NZSC drainage classes 4-5 (moderately well and well drained). About $70 \%$ of the farmed area is in well drained soils. In Southland, poorly drained soils are generally mole and tile drained when used for dairying (J. Risk, Environment Southland, personal communication). Therefore, poorly drained soils under dairying were assumed to have an artificial drainage system in place.

\subsection{Model Setup}

To examine the financial and environmental performance of representative sheep and beef and dairy systems in Southland, the farm-scale models Farmax ${ }^{\circledR}$ Pro (version 6.4.6.07; herein Farmax) and Farmax ${ }^{\circledR}$ Dairy Pro (Version 6.4.0.12) were linked with OVERSEER ${ }^{\circledR}$ (Version 6.0; herein Overseer), a nutrient budget model. Farm physical characteristics and livestock policies were exported from Farmax to parameterise Overseer. On-farm nitrate-N leaching and greenhouse gas (GHG) emissions (methane, nitrous oxide and carbon dioxide), all expressed as $\mathrm{CO}_{2}$ equivalents $\left(\mathrm{CO}_{2}\right.$-e), were assessed.

Farming systems representative of the region were modelled. Sheep and beef systems were sourced from Beef \& Lamb New Zealand (B+LNZ). Dairy systems were defined using DairyNZ publications (Facts and Figures for New Zealand Dairy Farmers, 2010) and expert opinion from AgResearch scientists (R. Monaghan and D. Stevens, personal communication). Dairy farms in New Zealand have been classified into 5 
production systems based on the timing and amount of feed brought onto the milking platform. Initially, a representative System 3 dairy farm was modelled in Farmax; this farm comprised a milking platform (190 ha for lactating cows exclusively) without a support area (area for replacement heifers and dry cows).

To maximise profit and minimise pasture utilisation and damage, Southland dairy farmers often send young stock and dry cows off the milking platform (Beukes et al., 2011). To account for a support area, a 230 ha System 3 dairy farm was modelled to include a milking platform area of 190 ha and an adjacent support area of 40 ha (Beukes et al., 2011) (Table 1).

Table 1. Livestock policies and profitability of a System 3 dairy farm on pasture production (PP) classes 1 to 4 in Southland. ${ }^{1}$ Farm profit before tax.

\begin{tabular}{|lrrrr|}
\hline & \multicolumn{4}{c|}{ Pasture production (PP) } \\
\hline \hline & 1 & 2 & 3 & 4 \\
Area (ha) & 230 & 230 & 230 & 230 \\
Cows (1 $1^{\text {st July) }}$ & 626 & 621 & 504 & 409 \\
MS (kg/ha) & 1,128 & 1,120 & 901 & 733 \\
MS (kg/cow) & 416 & 417 & 414 & 414 \\
$\mathrm{~kg} \mathrm{DMI} / \mathrm{kg} \mathrm{MS}$ & 12.0 & 11.9 & 11.9 & 11.9 \\
$\mathrm{~kg} \mathrm{LW} / \mathrm{t} \mathrm{DM}$ & 81.9 & 81.9 & 82.4 & 82.7 \\
$\mathrm{DMI}(\mathrm{t} \mathrm{DM} / \mathrm{ha})$ & 13.1 & 13.0 & 10.5 & 8.5 \\
Profit $^{1}$ (NZ\$/ha) & 2,898 & 2,858 & 1,732 & 825 \\
\hline
\end{tabular}

To accommodate all dairy livestock categories in the region within this modelling exercise, young stock (replacement heifers) were sent to sheep and beef farms by mid December and returned pregnant to the dairy farms by late May. This system was considered for regional up-scaling, since maintaining wintering cows on-farm ensured that cow numbers were kept proportional to dairy farm areas and allowed for a more comprehensive capture of nutrient losses and financial outcomes. on PP classes 2 to 6 . The B+LNZ Class 6 farm is the dominant sheep and beef farm class in the South Island. All feed was produced on-farm and a medium level of productivity was assumed, to represent average production and profit similar to those from B+LNZ (2010) (Table 2).

Table 2. Livestock policies and profitability of a Class 6 sheep and beef farm on pasture production (PP) classes 2 to 6 in Southland. ${ }^{1}$ Based on intake. ${ }^{2}$ Farm profit before tax.

\begin{tabular}{|lrrrrr|}
\hline \multicolumn{5}{c|}{ Pasture production (PP) } \\
\hline \hline & 2 & 3 & 4 & 5 & 6 \\
Area (ha) & 450 & 450 & 450 & 450 & 450 \\
Stock (SU/ha) & 17.0 & 14.2 & 12.6 & 9.4 & 5.7 \\
Sheep (\%) $^{1}$ & 86 & 86 & 86 & 77 & 77 \\
Beef (\%) $^{1}$ & 10 & 10 & 10 & 20 & 20 \\
Animal production (kg/ha) $^{1}$ & & & & \\
$\quad$ Meat & 252 & 211 & 186 & 138 & 83 \\
Total & 325 & 272 & 239 & 173 & 105 \\
Profit $^{2}$ (NZ\$/ha) & 434 & 315 & 236 & 147 & -26 \\
\hline
\end{tabular}

Reproductive efficiencies were considered equivalent for all PP classes; ewe pregnancy, lambing and weaning percentages were set at 166,130 and $126 \%$, respectively. Farm pre-tax profit was calculated as the difference between total farm gross revenue (from Farmax Pro) and total farm expenses (from Farmax Pro and B+LNZ Economic Service, Sheep and Beef Farm Survey, Forecast 2010-11).

\subsection{Regional Up-Scaling}

To estimate the impacts of potential conversion on a regional scale, model outputs from Farmax and Overseer were linked with actual farms obtained from AgriBase ${ }^{\circledR}$. The regional farm profit before tax $\left(F P_{i}\right)$ was calculated as:

$F P_{i}=\sum F P_{D} * A_{D}+F P_{S \& B} * A_{S \& B}$

where $F P_{D}$ and $F P_{S \& B}$ are the profit (NZ\$/ha) for dairy and sheep and beef, and $A_{D}$ and $A_{S \& B}$ are the farm areas (ha) under dairy and sheep and beef.

For annual $\mathrm{N}$ leaching (Figure 3) and GHG emissions (Figure 4), separate regression analyses were 
Vibart et al., Potential for land use change to dairy in Southland, New Zealand

conducted for well and poorly drained soils. Annual N leaching $(\mathrm{kg} / \mathrm{ha})$ for dairying on well drained $\left(N_{D w}\right)$ or poorly drained $\left(N_{D p}\right)$ soils was calculated as:

$N_{D w}=-6.5 \overline{P P w_{1-4}}+51$ and $N_{D p}=-5 \overline{P P p_{1-4}}+41$

Similarly, annual $\mathrm{N}$ leaching for sheep and beef on well drained $\left(N_{S \& B w}\right)$ or poorly drained $\left(N_{S \& B p}\right)$ soils was calculated as:

$N_{S \& B w}=-2.2 \overline{P P w_{2-6}}+21$ and $N_{S \& B p}=-1 \overline{P P p_{2-6}}+14$

Annual GHG emissions ( $\mathrm{kg} \mathrm{CO}$-e/ha) for dairying on well drained $\left(G H G_{D w}\right)$ or poorly drained $\left(G H G_{D p}\right)$ soils were calculated as:

$G H G_{D w}=-1568 \overline{P P w_{1-4}}+13298$ and $G H G_{D p}=-1795 \overline{P P p_{1-4}}+15682$

Annual GHG emissions for sheep and beef on well drained $\left(G H G_{S \& B w}\right)$ or poorly drained $\left(G H G_{S \& B p}\right)$ soils was calculated as:

$G H G_{S \& B w}=-901 \overline{P P w_{2-6}}+7709$ and $G H G_{S \& B p}=-1221 \overline{P P p_{2-6}}+9674$

The up-scaling for profit (NZ\$/ha) was conducted in a similar way to $\mathrm{N}$ leaching and GHG (Eq. 2 to 5).
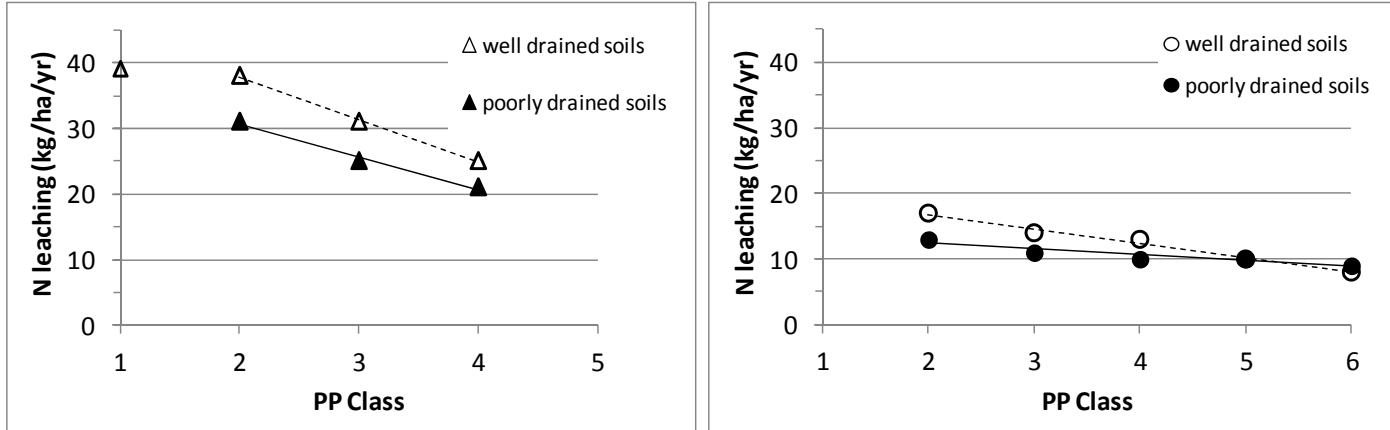

Figure 3. Annual $\mathrm{N}$ leaching (kg N/ha) simulated by Overseer for hypothetical dairy (left) and sheep and beef (right) farms in Southland as a function of pasture production (PP) class. Dairy farms were modelled on PP classes 1 to 4, whereas sheep and beef farms were modelled on PP classes 2 to 6 .
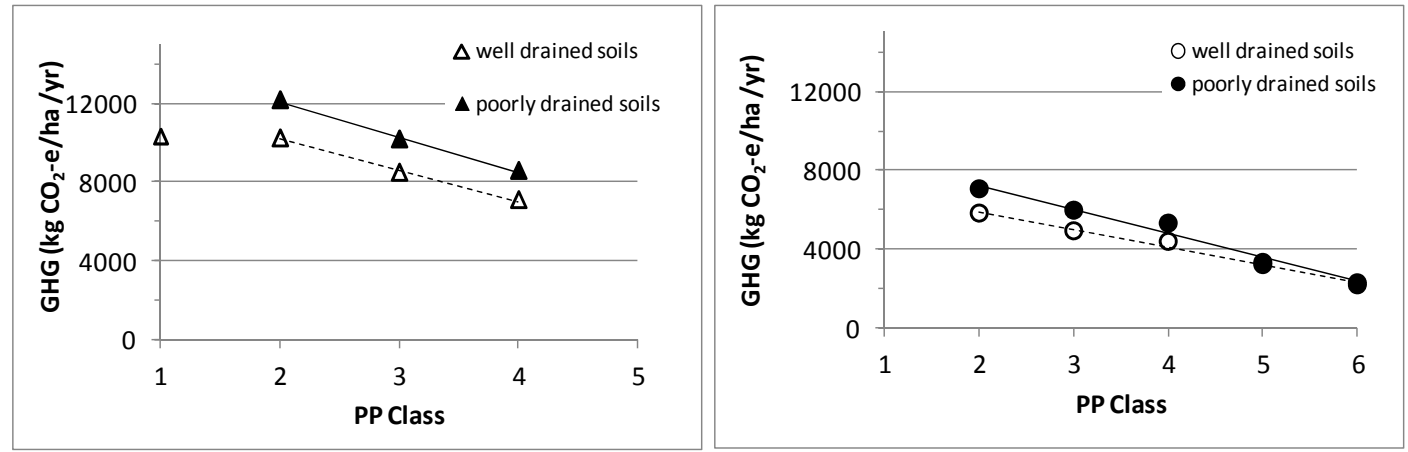

Figure 4. Annual GHG emissions (kg CO2-e/ha) simulated by Overseer for hypothetical dairy (left) and sheep and beef (right) farms in Southland as a function of pasture production (PP) class. Dairy farms were modelled on PP classes 1 to 4, whereas sheep and beef farms were modelled on PP classes 2 to 6 . 


\section{RESULTS AND DISCUSSION \\ 3.1. Farm System Modelling}

The results from the modelled farms were related to their corresponding PP class. Farm profit from dairying increased with increasing PP class (Table 1). These results are consistent with findings from van Bysterveldt (2005), who found a positive correlation between dairy farm profitability and pasture consumed per hectare. These results, along with the ones reported for sheep and beef (Table 2), are also in agreement with those reported by Copland and Stevens (2012) for Southland (NZ\$450/ha for a sheep and beef farm stocked at 11.4 $\mathrm{SU} /$ ha, equivalent to our PP Class 4 , and NZ $\$ 1,000 /$ ha for dairy).

Losses from $\mathrm{N}$ leaching and $\mathrm{N}$-derived GHG are associated with soil drainage characteristics (Monaghan et al., 2008). Overseer simulation results are presented for well drained Brown soils and poorly drained Pallic soils in Southland (Figure 3). Modelled annual N leaching values from dairy farms ranged from 21 to $44 \mathrm{~kg}$ $\mathrm{N} / \mathrm{ha}$, and were higher for farms with greater PP class, mainly due to the greater amount of $\mathrm{N}$ cycling and increased number of urine patches from the higher number of livestock carried. These values were within the range reported for dairy farms in Southland (Monaghan et al., 2008). Annual N leaching from the sheep and beef farms ranged from 8 to $17 \mathrm{~kg} \mathrm{~N} / \mathrm{ha}$, in agreement with reported values from sheep-grazed pastures in New Zealand (Magesan et al., 1996).

Annual GHG emissions were also higher from farms with greater PP class, and ranged from 7.1 to $15.4 \mathrm{t}$ $\mathrm{CO}_{2}$-e/ha for dairy and from 2.1 to $6.9 \mathrm{t} \mathrm{CO}_{2}$-e/ha for sheep and beef farms (Figure 4). In contrast to leaching, GHG emissions were higher from poorly drained soils compared with well drained soils; nitrous oxide $\left(\mathrm{N}_{2} \mathrm{O}\right)$ emissions are known to be higher in wet, poorly drained soils (De Klein et al., 2003). Annual $\mathrm{N}_{2} \mathrm{O}$ accounted, on average, for $22 \%$ and $35 \%$ of total GHG emissions from dairy farms on well-drained soils and poorly drained soils, respectively, and up to $40 \%$ from sheep and beef farms on poorly drained soils.

\subsection{Land Use Change}

Current (Scenario 1) and future (Scenario 2) land use scenarios were modelled to estimate the impacts of land use change from sheep and beef to dairy. In Scenario 2 we assumed that only farms that have a minimum of 230 ha in PP Classes 1 to 4 can convert to dairying (Table 3). Under Scenario 1, almost all of the required replacement heifers are raised on sheep and beef farms, whereas under Scenario 2 only a small percentage of the heifers are accounted for, and most of the heifers would need to be raised outside the region.

Table 3. Farm characteristics from two land use scenarios (Scenario 1 the current mix, Scenario 2 potential dairy conversion) in Southland. 1Dairy Heifers raised in sheep and beef farms.

\begin{tabular}{|lrr|}
\hline & Scenario 1 & Scenario 2 \\
\hline \hline Area in dairy (\%) & 15 & 46 \\
No. of dairy farms & 754 & 1,421 \\
Avg. dairy farm size (ha) & 220 & 346 \\
Avg. dairy herd size & 506 & 743 \\
Dairy heifers required & 80,172 & 221,862 \\
Heifers in $\mathrm{S} \& \mathrm{~B}^{1}(\%)$ & 95 & 11 \\
Profit $(\mathrm{NZ} \$ \mathrm{ha})$, all farms & 462 & 815 \\
$\mathrm{~N}$ leaching $(\mathrm{kg} \mathrm{N} / \mathrm{ha})$ & 13.1 & 17.5 \\
GHG $(\mathrm{kg} \mathrm{CO}$-e/ha) & 4,648 & 5,750 \\
\hline
\end{tabular}

A shift in land use from the current $15 \%$ of land area under dairying to a potential $46 \%$ led to a large increase in regional profit $(76 \%)$. The environmental impact from this land use change, however, became substantial, with regional nitrate leaching increasing by $34 \%$ and GHG emissions by $24 \%$ (Table 3 ).

The mean annual dairy farm profit decreased from NZ\$2,039 to NZ\$1,858/ha, due to the overall lower PP of land available for conversion. It should be noted that the diversity in individual farmer performance and management was not accounted for in this modelling exercise and could result in varying profits for any given property.

The new dairy farms resulting from conversion would largely fall in an N leaching range of 25 to $31 \mathrm{~kg} \mathrm{~N} / \mathrm{ha}$ (Figure 5) and a GHG emissions range of 7,000 to $10,500 \mathrm{~kg} \mathrm{CO}_{2}$-e/ha. Depending on future regional regulations that may be implemented, a large number of potential dairy farms might leach more $\mathrm{N}$ than the allowable limit, and mitigation techniques will need to be implemented. 


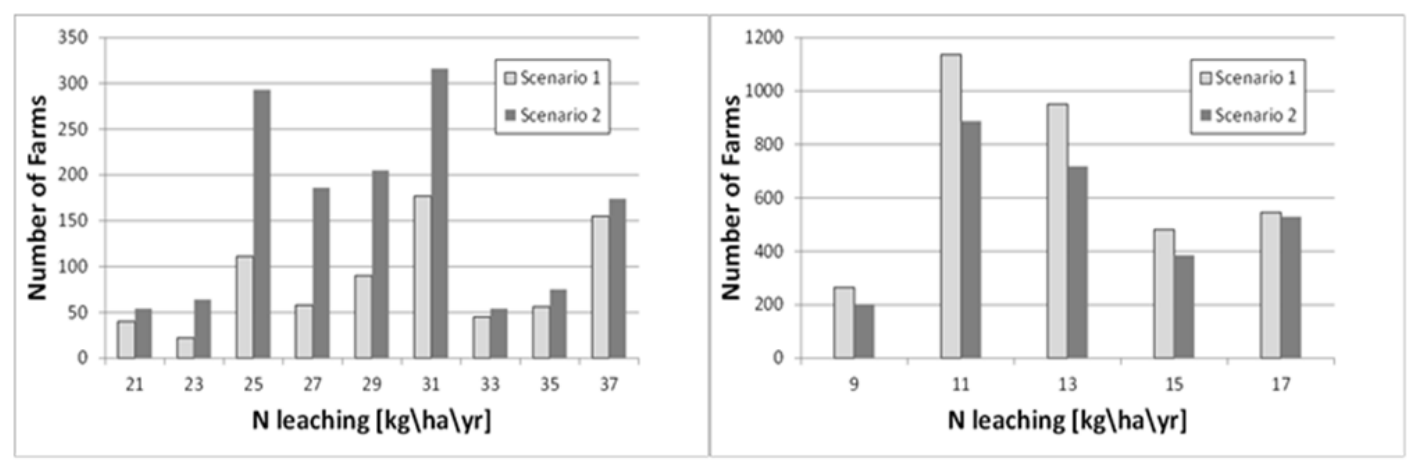

Figure 5. Distribution of $\mathrm{N}$ leaching as predicted by Overseer for hypothetical dairy (left) and sheep and beef farms (right) based on the current (Scenario 1) and potential (Scenario 2) number of farms.

Conversion of more farms into dairying increased farm profit, $\mathrm{N}$ leaching and GHG emissions in the region compared with the current situation. It must be noted that the up-scaling of potential dairy conversion was based on the land resources found in Southland. Actual levels of conversion could differ substantially from the single scenario that was explored here.

\section{ACKNOWLEDGMENTS}

This work was conducted under the Rural Futures Programme, which is funded by the Ministry of Business, Innovation and Employment (MBIE) New Zealand, through AgResearch Core Funding.

\section{REFERENCES}

Beukes, P.C., Gregorini, P., Romera, A.J., Dalley, D.E., 2011. The profitability and risk of dairy cow wintering strategies in the Southland region of New Zealand. Agricultural Systems 104, 541-550.

Copland, R.J., Stevens, D.R., 2012. The changing face of southern New Zealand farming: opportunities of land use change. Proceedings of the New Zealand Grassland Association 74, 1-6.

de Klein, C.A.M., Barton, L., Sherlock, R.R., Li, Z., Littlejohn, R.P., 2003. Estimating a nitrous oxide emission factor for animal urine from some New Zealand pastoral soils. Australian Journal of Soil Research 41, 381-399.

Lynn, I.H., Manderson, A.K., Page, M.J., Harmsworth, G.R., Eyles, G.O., Douglas, G.B., Mackay, A.D., Newsome, P.J.F., 2009. Land Use Capability Survey Handbook - A New Zealand handbook for the classification of land. Agresearch, Landcare Research, GNS Science.

Magesan, G.N., White, R.E., Scotter, D.R., 1996. Nitrate leaching from a drained, sheep-grazed pasture. I. Experimental results and environmental implications. Australian Journal of Soil Research 34, 55-67.

Monaghan, R.M., de Klein, C.A.M., Muirhead, R.W., 2008. Prioritisation of farm scale remediation efforts for reducing losses of nutrients and faecal indicator organisms to waterways: A case study of New Zealand dairy farming. Journal of Environmental Management 87, 609-622.

Monaghan, R.M., Wilcock, R.J., Smith, L.C., Tikkisetty, B., Thorrold, B.S., Costall, D., 2007. Linkages between land management activities and water quality in an intensively farmed catchment in southern New Zealand. Agriculture, Ecosystems \& Environment 118, 211-222.

NPS, 2011. National Policy Statement Freshwater Management. http://www.mfe.govt.nz/publications [accessed 12 May 2013].

Smith, A.P., 2012. Long term pasture growth patterns for Southland New Zealand: 1978 to 2012. Proceedings of the New Zealand Grassland Association 74, 147-152.

van Bysterveldt, A. 2005. Lincoln University dairy farm, now a cropping farm? pp 18-29 In: Proceedings of the South Island Dairy Event. 